\title{
A Win-Win Approach to Promoting Cooperation between Business Organizations and Business Education: The Role of Internships
}

Mahmoud M. Yasin

East Tennessee State University - Department of Management \& Marketing

P.O. Box 70625 -Johnson City, TN 37614

Carlos F. Gomes

University of Coimbra - School of Economics

Av. Dias da Silva 165 - 3004-512 Coimbra - Portugal

\section{Phillip E. Miller}

East Tennessee State University - Department of Management \& Marketing

P.O. Box 70625 -Johnson City, TN 37614

This is a post-print (i.e. final draft post-refereeing) of an article published in International Journal of Process Management and Benchmarking (ISSN: 1460-6739), available online at:

https://www.inderscienceonline.com/doi/pdf/10.1504/IJPMB.2015.072330

Citation: Yasin, Mahmoud M., Gomes, Carlos F. e Miller, Phillip E. (2015), "A Win-Win Approach to Promoting Cooperation between Business Organizations and Business Education: The Role of Internships", International Journal of Process Management and Benchmarking, 25 (4), pp. 499-514. 


\title{
A Win-Win Approach to Promoting Cooperation between Business Organizations and Business Education: The Role of Internships
}

\begin{abstract}
Utilizing internship evaluation forms of students from different majors, who were attending two universities in USA, and Portugal, this research sought to assess relevant abilities, skills, and attitudes impacting the job performance of these students during their internships. Based on the evaluations analysed, it appears that executives of business organizations tended to value other non-technical aspects of performance, rather than merely the technical aspects. The implications and recommendations of this research to business education, and the business community are presented in the form of two conceptual frameworks. The frameworks are designed to promote win-win relationships, which enhance the employability of business graduates. The proposed frameworks stress the consistency, and the systematic approach to the business-like educational model.
\end{abstract}

Keywords: Business organizations, Business education, Internships, Performance, Process, Benchmarking, Employment, Win-win joint venture. 


\section{A Win-Win Approach to Promoting Cooperation between Business Organizations and Business Education: The Role of Internships}

\section{INTRODUCTION}

The success of any system must be gauged systematically, and frequently. Therefore, issues and concerns related to performance measurement, and overall management are becoming a necessity, rather than a luxury. Manufacturing systems and service systems, are being called upon by a changing environment to pay closer attention to the multidimensional aspects of performance measurement and management (Tung et al. 2011; Veysel et al. 2012; Bourne et al. 2012; Laats et al. 2011). In this context, there are no exceptions. As such, higher education schools are getting more and more attention to these issues (Asif et al. 2013; Franceschini \& Turina 2013; Collan et al. 2014).

Business systems have been moving away from a business model, which emphasizes a closed system perspective, where efficiency is the main determinant component of performance. In recent years, business organizations have adopted a more open system perspective, where effectiveness is the major determinant component of performance. In this process of organizational strategic change, business systems have deployed innovative operational technologies, process improvement initiatives, and customer-oriented strategies (Augusto et al. 2014).

Recently, the majority of higher education institutions have modified their instructional delivery methods. Nowadays, terms, such as on-line education, digital education and electronic education, are increasingly colouring the landscape of higher education. Emerging educational technology have been open a new horizon of instructional design and learning effectiveness (Novak et al. 2012). 
Despite such an apparent shift from traditional, lecture-based approach of instruction, to a more technological-based method, it is argued that institutions of higher education remain, for the most part, closed rather than open system-oriented. Some scholars and business leaders have argued that higher business education is still emphasizing a subject-based approach, rather than a problem solving-based practical approach. Therefore, higher business education, for the most part, is still focusing on the wrong courses, programs, and approaches as it prepares students for the job market. Therefore, it is no surprise that graduates of the closed system-oriented higher business education are facing employment difficulties. In this context, there is an apparent gap between the expectations of the job market and the preparation of business students.

Many scholars and business leaders have called for joint efforts to close this gap. However, to date, such win-win joint venture efforts still remain the rare exception, rather than the rule. In this context, both sides are blaming one another, rather than combining efforts to make students more employable, and in the process promoting economic growth.

In recent years, several studies proposed the concept of internships as a means of narrowing the gap between business education and business schools, in terms of their preparation of students (Taylor \& Hooley 2014). In addition, internships were promoted as tools to enhance employment, career development, and marketability of business students (Gault et al. 2010; Green 2011a; Dumitru et al. 2012; Taylor \& Hooley 2014). Some studies underline the benefits of internships to both the business community as well as business schools (Weible 2009; Green 2011b; Dumitru et al. 2012). In essence, these studies point to the mutual practical benefits of internships in different business contexts. Therefore, business education with the cooperation of their business communities might utilize the concept of practical internships to eliminate the gap between business 
expectations and skillset offered to business students during their training in business schools.

While internships might not eliminate the gap between the business community and higher business education, they should contribute to reducing it. In this context, internships help in understanding the expectations of business, relative to the preparation of the students by higher business education. Such understanding might allow higher business education to reengineer its approach to programs of study and specific courses and skills emphasis, as it prepares students for the job market. Such reengineering efforts might lead to a better match between the set of skills and characteristics sought after by the business community, and those being offered by higher business education.

Against this backdrop, the objective of this research is twofold. First, using data collected from internship forms, from East Tennessee State University in the USA, and University of Coimbra in Portugal, are examined to uncover relevant characteristics and abilities of business students from the perspective of potential employers. Students from these two universities represent different cultural backgrounds. The utilization of these different samples should broaden and enrich the utility of the conclusions and implications. Second, implications and recommendations to institutions of higher business education, and business organizations toward the elimination of or, at least, reducing the gap between business expectations and business education preparation are offered. In this process, a win-win approach based on two conceptual frameworks is presented. The conceptual frameworks advocated in this study attempt to promote the following goals:

1. The need to have internally consistent measurement processes, within higher business education. 
2. The need to understand the demands of the business community in terms of the skills and abilities of business students needed for employment.

3. The need for strengthening the communication and cooperative partnerships between the business community and its higher business educational counterpart.

4. The need for sharing benchmarking information between the business community and higher business education.

5. The need for these important societal instructors to work together toward promoting employment and economic growth. This necessity will require the willingness of tangible and intangible pressures and expertise.

Overall, the approach advocated in this research focuses on the role of internships, as a means to bridge the gap between business organizations and business higher education institutions. The establishment of true, and win-win joint strategic ventures between business organizations and business higher education should facilitate employment of graduate business students, as well as the promoting of sharing of know-how between these two institutions of any society.

The remainder of this paper is organized based on the following major sections. First, the relevant literature is presented. Second, the methods used to analyse the two studies are presented. Third, the discussion of results is presented. Finally, the conclusions and implications of this research are offered. In this context, the applied research is focused on important and practical society concerns. Therefore, it is not designed to develop a specific theory. The two conceptual frameworks offered in this research might encourage future researchers to refine the conceptual and preliminary nature of these proposed frameworks into theoretical models. Such models, after validation in different cultural settings have the potential to advance the theory and practice of business education and its relation to the business community. 


\section{RELEVANT LITERATURE}

\subsection{The Business System Performance}

A well-cited article which traced the development of the literature dealing with performance measures and measurement of business organizations concluded that these organizations have moved from the closed system-orientation (traditional and financial measures), to a more broader, and multi-faceted approach to performance management (Gomes et al. 2004). In this context, Gomes \& Yasin (2011a) proposed two platforms for performance measures and measurement for today's open business system organization. The first platform focused on specific dimensions of the performance system. On the other hand, the second platform focused on the overall strategic role of the performance system performance (Gomes \& Yasin 2011a).

The shift to the open system business model was facilitated by the adoption of innovative process improvement initiations, such as just-in-time (JIT), Process Engineering (PE), Benchmarking (BM), Continuous Improvement (CI), and Total Quality Management (TQM), among others, (Yasin, Small, et al. 2011; Small et al. 2011). The role and nature of these organizational innovations and initiatives are also addressed by Seethamraju (2012), who extended the work of others (McCormack \& Johnson 2001; Malekzadeh 1998).

The shift toward a more open system model of business, which many of today's business organizations are aspiring for, incorporates and focuses on benchmarking of competitive performance (Rahebe Keshavarzi \& Abooie 2013; Weerasinghe et al. 2014; Krishnamoorthy \& D'Lima 2014), innovation management and improved services (Yu \& Huang 2014). The innovations associated with this shift target manufacturing technology (Matawale et al. 2013), as well as customer orientation with its different facets (Murugan 
\& Rajendran 2013; Susanti 2014). In addition, the efforts of these organizations are geared towards employee improvement (Wong \& Cheung 2014) and suppliers (Sahu et al. 2013).

Open system organizations are incorporating social responsibility and sustainability (Vimal \& Vinodh 2013) into their overall strategy. Therefore, the business approach followed by open system organizations stresses openness, performance improvement, and the development of the human capital, without ignoring their social responsibility and obligations to their communities.

The deployment of the above initiatives enhanced the operational efficiency, flexibility (Yasin, Gomes, et al. 2011; Yasin, Small, et al. 2011), and the customerorientation of the open system business organizations. This, in turn, tended to improve, in some cases, the bottom line for the organization (Yasin et al. 2004).

\subsection{The Higher Education Performance System}

Traditionally, higher business education systems have been characterized as closed systems (Czuchry \& Yasin 2008; Yasin et al. 2005; Seethamraju 2012). As such, these systems were internally-focused, and were designed to offer specific functional technical knowledge (Anninos \& Chytiris 2011). The subject-based and programspecific, closed system perspective was in direct conflict with the evolving, dynamic needs of the business open system. Calls to reform the closed system-orientation of higher business education were adopted by business organizations and by governments (Frølich \& Stensaker 2010; Winkel 2010; Floud 2006). The performance associated with the closed system of higher business education was consistent with the needs of the technical expertise, required by the efficiency-based closed business system. However, such educational performance-orientation slowly became inconsistent with demands of 
the open business system-orientation of today's business organizations (Širca et al. 2006; Jurše \& Tominc 2008). Modern business organizations are in need of well-rounded potential leaders, rather than mere technical experts, who are unable to relate to the organization and its customers (Gilbert 2012; Seethamraju 2012).

Most higher business education institutions have attempted to respond to the increasing pressures for aligning their systems with the realities of the changing job market (Daud et al. 2011; Czuchry et al. 2004; Azevedo et al. 2012). In this context, they initiated changes focused on new technologies to deliver instructions, modifications emphasizing on outcomes-based learning, introduction of innovative programs/majors, as well as emphasizing some skills demanded by the open business system. These innovations were aimed at enhancing critical thinking skills, entrepreneurship, training and the promotion of cross disciplinary approaches to business education (Bandyopadhyay et al. 2013; Czuchry et al. 2004).

Consistent with this orientation, is the efforts of some business schools to reengineer their approaches to faculty evaluation in order to emphasize a more balanced approach (Collan et al. 2014). This approach emphasizes both the discipline-specific skills, as well as the generic softer skills when preparing students for the employment (Andrews \& Higson 2014; Beenen 2014).

Despite efforts to change the orientation of the closed educational system, the gap between traditional educational preparation, and recent organizational performance expectations remains subjects of major concern among scholars and practitioners (Agut \& Grau 2002; Agut et al. 2003; Digman 1990; King et al. 2001; Kimball 1998; Davenport et al. 2004).

Whatever initiating higher business education institutions undertook in an attempt to modify their educational model, they appeared to be insufficient toward satisfying the 
needs of the open business system organizations. Institutions of higher learning still appear to be having difficulties in placing their graduates in the job market. Specifically, these students appear to be unemployable because they do not have the right preparation and skills needed by the new realities of the job market. In this context, some aspects of the business educational system have changed. However, such changes have not yet been enough to modify and improve the performance of educational closed systems. Although performance specific-measures (outcomes) appeared to slowly being implemented by most institutions of higher business education, such effort has not yet resulted in better students' employment. Perhaps major changes regarding strategic performance concerns still are not being implemented. Therefore, the gap between business expectations and business educational preparation remains. In the process, students are faced with difficulties in finding meaningful employment.

\subsection{Employment and Desired Skills}

Due to the misalignment between the performance of the higher business educational system and the performance needs of the business organization system, the potential for employment of students is becoming a selling point for most business schools (Andrews \& Higson 2008; Van Der Heijden 2002). This is especially true during difficult economic times.

While employment as a construct is multifaceted in nature (Wickramasinghe \& Perera 2010; Yorke \& Knight 2007; Andrews \& Higson 2008), it practically focuses on matching one's competencies and skills consistent with the requirements of a given job. It has been argued that the mismatch between one's competencies and skills, which are gained during the educational business preparation process, and the competencies and skills required for a job tend to contribute to unemployment (Mason et al. 2009; Wilton 
2008). Cornuel (2007) stressed the idea of integration of research and teaching in order to produce professionally qualified students, who are employable in a global job market.

Therefore, the practical and organizational skills, which business education should offer must be relevant to the employability of the business graduates. Among these skills relevant are entrepreneurial, problem-solving, ability to work with others and critical thinking skills. These important skills are needed for future business managers. In addition, business organizations are also looking for effective communicators, leaders, and decision-makers (Jusoh et al. 2011).

These skills are as important, if not more important, than mere technical, specific skills. Schoemaker (2008) emphasized conceptual skills, ability to handle ambiguity, and complexity as desirable characteristics, which business education should stress. In short, business educational systems must become more open systems with an emphasis on the customer-orientation approach, which is consistent with the demands of their business systems counterparts (Starkey \& Tempest 2008).

As business education attempts to re-orient its system in order to make its graduating students more employable, internships could be viewed as an important part of this effort. In this context, internships help in bridging the gap between business education preparation and business organizations' performance expectations (Chi \& Gursoy 2009; Liu et al. 2011). Perhaps this might explain the increasing, support internships are beginning to receive from business education institutions, and the business community (Gault et al. 2000; Callanan \& Benzing 2004; D'Bate et al. 2009; Liu et al. 2011).

The importance of internships to both communities provides the motivation for the current research. This research analyses data collected from the internship evaluation forms of one hundred fifty-two (152) business undergraduate students from East 
Tennessee State University. One hundred forty-five (145) internship evaluation forms of business undergraduate students from the University of Coimbra were also analysed. Therefore, the sample used in this study represents two different business cultural and educational backgrounds and realities.

\section{METHODS}

\subsection{Procedure}

For the purpose of this research, records of evaluations' forms for business students from the two universities mentioned earlier were obtained and analysed to uncover the important skills which managers are emphasizing, as they evaluate the overall performance of the students upon completion of their internships. Therefore, the instruments used in this research are essentially the evaluations' forms used by the two universities. These forms were coded and the names of the students and evaluators were concealed to protect the privacy of the students and the evaluators by an individual, who was not part of the research team.

The forms included several dimensions and variables relevant to the skills of the students. These dimensions and variables included different personal characteristics, managerial know-how, and organizational concerns. Furthermore, the two forms were not the same in terms of the performance dimensions and variables, which they address. Perhaps inconsistency was attributed to the different cultural business settings of this study.

During the first phase of data analysis, descriptive statistics was used to portray the performance profile of students' performance during their internship. In the second phase, content analysis was used to analyse the comments of evaluators regarding students' performance. Among these analysis themes stressing the non-technical aspects of the performance of the students emerged. These themes stressed the softer skills, which the 
evaluations appear to emphasize. These softer dimensions included leadership abilities, able to work with others, dependability, timely completion of tasks, and ability to identify and solve problems, among others.

\subsection{Samples}

For the purpose of this research, records of evaluation forms for one hundred and forty-five (145) undergraduate business students from University of Coimbra School of Economics in Portugal, who completed their internships, were analysed. In these evaluation forms, executives of business organizations were asked to classify students' performance during their internships. In addition, executives were asked to evaluate the student internships along different performance related dimensions, as well as their overall evaluation of the students' performance.

One hundred and fifty-two (152) business undergraduate students from East Tennessee State University College of Business and Technology in the USA, who completed their internships, were also analysed. In these evaluation forms, executives were asked to evaluate the students' performance during their internships. The business executives were asked to evaluate the student internship's overall job performance, as well as the performance along several related dimensions.

\section{RESULTS AND DISCUSSION}

\subsection{University of Coimbra}

Based on the data analysed, the following results were derived. Despite demands of the Portuguese business organizations, the entrepreneurship innovation and leadership related skills appeared to still be underemphasized by business education. Portuguese executives in their evaluations of students' performance underscored these 
skills. Therefore, Portuguese business educators might incorporate the demands of the executives as they reengineer their business curriculum.

Some key business performance aspects, such as putting more emphasis on practical training and the effective utilization of information technology applications, appeared to be valued highly by business organizations. Although Portuguese business schools have made some strides towards responding these demands, the executives of surveyed business organizations were still demanding more educational changes.

Today's business organizations are in search of leaders, rather than technical managers. They are valuing leadership skills which focus on undertaking innovative approaches to business problems, while taking the responsibility for their actions and bold decisions. As business schools prepare the future business leaders, they should take into account the new realities and demands of the Portuguese business environment. The most important skills stressed by executives were non-technical in nature. In this context, awareness of the elements of the organizational culture and how to deal with them appeared to be very important to those executives.

Finally, as business education attempts to reengineer its operational model in order to be more consistent with the open system business model, it must be willing to adopt new approaches and emphasize leadership, which can be coupled with the specific technical expertise. In this context, the integration of the different aspects of business education into a comprehensive approach, must stress innovation-based problem-solving and leadership-orientation.

\subsection{East Tennessee State University}

Similar analysis, were conducted for ETSU business students. The results also tended to stress the softer aspects of business. Again this was the case regardless of major of study. 
Business organizations, as open systems, appeared to value an integrated and a multifaceted performance. Such orientation was evident by emphasizing efficiency, as well as additional aspects of performance, such as quality of the performed tasks. In addition, other dimensions of performance, such as dependability, effectiveness, and relationships to others were also stressed. In this context, it appeared that the surveyed organizations were not looking for, merely, technical knowledge and efficiency, as the sole determinant of performance. Therefore, business education should re-orient its strategies and practices in order to promote multifaceted skills, which are conducive to the different aspects of effective performance on the job.

Regardless of the program of study (major), softer performance dimensions were very much valued by the business executives. Although the technical knowledge for each major was different, the important organizational aspects of the effective performance appeared to be somewhat similar and non-technical in nature. In this context, business organizations appeared to be looking for leaders, who understand the organizational context and their people. This orientation requires a different skills set than the skills promoted by specific technical orientation offered by the course-specific knowledge utilized in the educational training of business schools. A problem-solving and a cross disciplinary approach appears to be more valued by business organizations.

\subsection{Comparative Results}

Table 1 summarizes the most relevant skills impacting performance of business students during their internship, as reported by business executives in the two samples studied. It is to be noted that these skills were non-technical in nature. While these skills differ from one business community to another, they tended to emphasize the need for business educators to evaluate their operational models. This includes programs and 
majors of study, as well as the approaches, methods of delivery, and strategies utilized in the process.

Insert Table 1 about here

Overall, it is concluded that business schools are in need of reorienting themselves in order to become more open systems. These open systems should adapt and interact freely with the dynamic environment, and the changing job market. In order for such reengineering to take place smoothly, business schools must first ensure the internal consistency between their efforts to assess their outcomes and the instruments they are using to capture information pertaining to internships and assessment of specific educational outcomes.

Also, business schools must interact with the business community in order to make sure they are measuring what needs to be measured, rather than what is easy to measure. The two conceptual frameworks advocated as a result of this study are designed to facilitate both objectives. Business education should be aware of the demands of the business community. On the other hand, the business community must share its resources and expertise in order to support the changing efforts of business schools toward a more responsive, open system model of business education. This cooperation will ensure the effectiveness of business education. Such joint effort should, among other things, promote employment of the waves of graduates of business schools. Therefore, this results in a win-win relationship among these important institutions of our society.

This process is by no means easy, as both business and business community have their own traditions and distinct cultures. However, both must be willing to cooperate through benchmarking best practices and process improvement techniques. As such, 
they must jointly initiate an integrated improvement process, which focuses on the emerging realities and demands for customer-oriented and technology-based business and educational practices. The two conceptual frameworks offered in this represent a modest step in this worthy cooperative process.

\section{CONCLUSIONS AND IMPLICATIONS}

This research utilized the actual evaluation forms obtained from business organizations for undergraduate business students, who completed their internships in two different business cultures. The business executives hosting the interns evaluated the students overall performance based on predetermined forms which included different performance aspects. This study attempted to shed some light on the performance practices of both business education systems, and business organization systems. Based on the results of this research and the literature examined, the following overall conclusions and their implications are in order.

First, business organizations, as open systems appeared to value integrated and multifaceted performance. That was evident by emphasizing efficiency, as well as additional aspects of performance such as quality, dependability, initiative, leadership skills, problem-solving, innovation, and relationships with others. This means that these organizations are not looking merely for technical expertise in order to promote organizational efficiency. In this context, business education should re-orient itself to promote multifaceted skills, which were found to be conclusive to the different aspects of effective performance on the job.

Second, despite the major of study, there were soft-performance dimensions, which were valued by the business executives. Although the technical knowledge in each major is different, the organizational aspects of the effective performance, appeared to be 
somewhat similar. Further, these skills were of the organizational nature rather than technical nature.

Third, as both business education institutions and business organizations are aspiring to become more customer-oriented, open systems, with integrated and multifaceted performance aspects, they should utilize internships to create win-win joint ventures. The conceptual frameworks in Figures 1 and 2 are designed to promote such win-win process in relation to performance improvements, which are important to both business organizations and business education.

Insert Figure 1 about here

Insert Figure 2 about here

Finally, business education institutions must focus on both performance-specific outcome measures, as well as on performance-global measures in order to close the performance gap with their business communities' counterparts. This requires paying closer attention to assessment of business education from a practical perspective. In this context, it is rather easy to set learning objectives, and assessment procedures, which are defined by business education itself. However, the true challenge is to do so jointly with the business leaders who are going to employ business students. In this context, there should be consistency between what the business institutions are measuring, and what business leaders are utilizing in their measurement of business performance. Internships, if used effectively, should provide business institutions with the needed information to adjust their systems, program offerings, processes, and their overall approach to effective and practical business-like performance. 
Therefore, instruments used to assess internship performance should be consistent with the expectations of the business community. Also, business education assessment instruments and efforts should be based on feedback obtained from business leaders (Gomes \& Yasin 2011b).

Simply put, it is not important for business schools to measure what they want to measure; rather it is more significant for them to measure what should be measured. In this context, the input of potential employers, in terms of the relevant performance dimensions to these organizations must be taken into consideration when developing the performance evaluation process of business education. In this context, future applied research is needed to establish and validate instruments designed to assess performance outcomes of internships. Such applied research should capitalize and in the process integrate the practical knowledge of business executives with the academic expertise of business educations. This will ensure that the gap, which has often hindered the effectiveness of business education and employment of the business student, is narrowed and, eventually, eliminated.

This study was based on predetermined internship evaluation forms. Therefore, it did not allow the evaluating executives to express their views of what they deem most valuable characteristics and skills as it presented them with already determined dimensions of performance. Also, the current study used relatively small samples from two business cultural settings. These factors represent limitations on the findings and conclusions of this study. Consequently, future research with broader scope and context is called for in this important area. Despite its limitations, this study offers future researchers a context in which they can study the impact of cooperation and benchmarking between business community in both different settings and institutions of 
higher business learning. The conceptual frameworks depicted in Figure 1 and 2 are offered towards that end. 


\section{REFERENCES}

Agut, S. \& Grau, R., 2002. Managerial competency needs and training requests: the case of the Spanish tourist industry. Human Resource Development Quarterly, 13(1), pp.31-52.

Agut, S., Grau, R. \& Peiró, J.M., 2003. Competency needs among managers from Spanish hotels and restaurants and their training demands. Hospitality Management, 22(3), pp.281-295.

Andrews, J. \& Higson, H., 2008. Graduate Employability, "Soft Skills" Versus "Hard” Business Knowledge: A European Study. Higher Education in Europe, 33(4), pp.411-422.

Andrews, J. \& Higson, H., 2014. Is Bologna Working? Employer and Graduate Reflections of the Quality, Value and Relevance of Business and Management Education in four European Union Countries. Higher Education Quarterly, 68(3), pp.267-287.

Anninos, L.N. \& Chytiris, L., 2011. Searching for excellence in business education. Journal of Management Development, 30(9), pp.882-892.

Asif, M., Raouf, A. \& Searcy, C., 2013. Developing measures for performance excellence: is the Baldrige criteria sufficient for performance excellence in higher education? Quality \& Quantity, 47(6), pp.3095-3111.

Augusto, M.G., Lisboa, J.V. \& Yasin, M.M., 2014. Organisational performance and innovation in the context of a total quality management philosophy: an empirical investigation. Total Quality Management \& Business Excellence, 25(9-10), pp.1141-1155.

Azevedo, A., Apfelthaler, G. \& Hurst, D., 2012. Competency development in business graduates: An industry-driven approach for examining the alignment of undergraduate business education with industry requirements. The International Journal of Management Education, 10(1), pp.12-28.

Bandyopadhyay, J., Coleman, L.J. \& DeWolfe, S., 2013. Interdisciplinary Education for global strategy. Advances in Competitiveness Research, 21(1 \& 2), pp.46-60.

Beenen, G., 2014. No Title. Academy of Management Learning \& Education, 13(1), pp. $88-101$. 
Bourne, M. et al., 2012. Generating organisational performance: measurement and human resource management practices. International Journal of Operations \& Production Management, 33(11), pp.1599-1622.

Callanan, G. \& Benzing, C., 2004. Assessing the role of internships in the employment of graduating college students. Education + Training, 46(2), pp.82-89.

Chi, C.G. \& Gursoy, D., 2009. How to help your graduates secure better jobs? An industry perspective. International Journal of Contemporary Hospitality Management, 21(3), pp.308-322.

Collan, M., Stoklasa, J. \& Talasova, J., 2014. On academic faculty evaluation systems more than just simple benchmarking. International Journal of Process Management and Benchmarking, 4(4), pp.437 - 455.

Cornuel, E., 2007. Challenges facing business schools in the future. Journal of Management Development, 26(1), pp.87-92.

Czuchry, A. \& Yasin, M.M., 2008. International entrepreneurship: The influence of culture on teaching and learning styles. Journal of Entrepreneurship Education, 11, pp.1-15.

Czuchry, A.J., Yasin, M.M. \& Gonzales, M., 2004. Effective Entrepreneurial Education: A Framework for Innovation and Implementation. Journal of Entrepreneurship Education, 7(1), pp.39-56.

D’Bate, C.P., Youndt, M.A. \& Wenzel, K.E., 2009. Making the Most of an Internship: An Empirical Study of Internship Satisfaction. Academy of Management Learning \& Education, 8(4), pp.527-539.

Daud, S. et al., 2011. Enhancing university business curriculum using an importanceperformance approach: A case study of the business management faculty of a university in Malaysia. International Journal of Educational Management, 25(6), pp.545-569.

Davenport, T.., Harris, J.G. \& Cantrell, S., 2004. Enterprise systems and ongoing process change. Business Process Management Journal, 10(1), pp.16-26.

Digman, J.M., 1990. Personality structure: Emergence of the Five-factor model. Annual Review of Psychology, 41, pp.417-440.

Dumitru, I., Cruceru, A.F. \& Căescu, Ş.C., 2012. The influence of graduates professional experience over general business perception. The Romanian Economic Journal, 15, pp.53-62. 
Floud, R., 2006. The Bologna Process: Transforming European Higher Education. Change: The Magazine of Higher Learning, 38(4), pp.8-15.

Franceschini, F. \& Turina, E., 2013. Quality improvement and redesign of performance measurement systems : an application to the academic field. Quality \& Quantity, 47(1), pp.465-483.

Frølich, N. \& Stensaker, B., 2010. Student recruitment strategies in higher education: promoting excellence and diversity? International Journal of Educational Management, 24(4), pp.359-370.

Gault, J. et al., 2010. Effects of business internships on job marketability: the employers ' perspective. Education + Training, 52(1), pp.76-88.

Gault, J., Redington, J. \& Schlager, T., 2000. Undergraduate Business Internships and Career Success: Are They Related? Journal of Marketing Education, 22(1), pp.45-53.

Gilbert, D.H., 2012. From chalk and talk to walking the walk: Facilitating dynamic learning contexts for entrepreneurship students in fast-tracking innovations. Education + Training, 54(2/3), pp.152-166.

Gomes, C.F. \& Yasin, M.M., 2011a. A systematic benchmarking perspective on performance management of global small to medium-sized organizations: An implementation-based approach. Benchmarking: An International Journal, 18(4), pp.543-562.

Gomes, C.F. \& Yasin, M.M., 2011b. Challenges to Business Education: The Gap between Practices and Expectations. International Journal of Business Research, 11(6), pp.169-178.

Gomes, C.F., Yasin, M.M. \& Lisboa, J. V, 2004. A literature review of manufacturing performance measures and measurement in an Organizational Context: A Framework and Direction for Future Research. Journal of Manufacturing Technology Management, 15(6), pp.511-530.

Green, J.P., 2011a. The impact of a work placement or internship year on student final year performance: An empirical study. The International Journal of Management Education, 9(2), pp.49-57.

Green, J.P., 2011b. The impact of a work placement or internship year on student final year performance: An empirical study. The International Journal of Management Education, 9(2), pp.49-57. 
Van Der Heijden, B., 2002. Prerequisites to guarantee life-long employability. Personnel Review, 31(1), pp.44-61.

Jurše, M. \& Tominc, P., 2008. Professional Competences of Graduates as a Labour Market Mechanism for Aligning Business School Curriculum Reform with the Bologna. Management, 13(1), pp.17-36.

Jusoh, M., Simun, M. \& Chong, S.C., 2011. Expectation gaps, job satisfaction, and organizational commitment of fresh graduates: Roles of graduates, higher learning institutions and employers. Education + Training, 53(6), pp.515-530.

Kimball, B., 1998. Practitioner methodology for entry-level hiring assessment: Issues for academic outcomes assessment. Journal of Education for Business, 73(3), pp.168-171.

King, A.W., Flower, S.W. \& Zeithaml, C.P., 2001. Managing organizational competencies for competitive advantage: The middle-management edge. Academy of Management Executive, 15(2), pp.95-106.

Krishnamoorthy, B. \& D’Lima, C., 2014. Benchmarking as a measure of competitiveness. International Journal of Process Management and Benchmarking, 4(3), pp.342 - 359.

Laats, K., Haldma, T. \& Moeller, K., 2011. Performance measurement patterns in service companies An empirical study on Estonian service. Baltic Journal of Management, 6(7621), pp.357-377.

Leeuw, S. De, Grotenhuis, R. \& Goor, A.R. Van, 2013. Assessing complexity of supply chains : evidence from wholesalers. International Journal of Operations \& Production Management, 33(8), pp.960-980.

Liu, Y., Xu, J. \& Weitz, B.A., 2011. The Role of Emotional Expression and Mentoring in Internship Learning. Academy of Management Learning \& Education, 10(1), pp.94-110.

Malekzadeh, A.R., 1998. Diversity, integration, globalization and critical thinking in the upper division. Journal of Management Education, 22(5), pp.590-603.

Mason, G., Williams, G. \& Cranmer, S., 2009. Employability Skills Initiatives in Higher Education : What Effects Do They Have On Graduate Labour Market Outcomes? Education Economics, 17, pp.1-30.

Matawale, C.R., Datta, S. \& Mahapatra, S.S., 2013. Interrelationship of capabilities/enablers for lean, agile and leagile manufacturing: an ISM approach. 
International Journal of Process Management and Benchmarking, 3(3), pp.290 313.

McCormack, K.P. \& Johnson, W.C., 2001. Business Process Orientation - Gaining Ebusiness Competitive Advantage, Boca Raton, FL.: St. Lucie Press.

Murugan, R. \& Rajendran, G., 2013. A three-dimensional approach to customer retention in mobile phone services. International Journal of Process Management and Benchmarking, 3(4), pp.494-510.

Novak, E., Razzouk, R. \& Johnson, T.E., 2012. The educational use of social annotation tools in higher education: A literature review. The Internet and Higher Education, 15(1), pp.39-49.

Rahebe Keshavarzi \& Abooie, M.H., 2013. Performance evaluation of continuous production process by trapezoidal fuzzy process capability indices. International Journal of Process Management and Benchmarking, 3(3), pp.371 - 385.

Sahu, S.K. et al., 2013. Supply chain performance appraisement, benchmarking and decision-making: empirical study using grey theory and grey-MOORA. International Journal of Process Management and Benchmarking, 3(3), pp.233289.

Schoemaker, P.J.H., 2008. The Future Challenges of Business: Rethinking Management. California Management Review, 50(3), pp.118-139.

Seethamraju, R., 2012. Business process management: a missing link in business education. Business Process Management Journal, 18(3), pp.532-547.

Širca, N.T. et al., 2006. The Labour Market, Graduate Competences and Study Programme Development: A Case Study. Higher Education in Europe, 31(1), pp.53-64.

Small, M., Yasin, M.M. \& Alavi, J., 2011. Assessing the implementation and effectiveness of process management initiatives at technologically consistent firms. Business Process Management Journal, 7(1), pp.6-20.

Starkey, K. \& Tempest, S., 2008. A clear sense of purpose? The evolving role of the business school. Journal of Management Development, 27(4), pp.379-390.

Susanti, C.E., 2014. The antecedence of customer loyalty in traditional restaurants in East Java, Indonesia. International Journal of Process Management and Benchmarking, 4(1), pp.22-35. 
Taylor, A.R. \& Hooley, T., 2014. Evaluating the impact of career management skills module and internship programme within a university business school. British Journal of Guidance \& Counselling, 42(5), pp.487-499.

Tung, A., Baird, K. \& Schoch, H.P., 2011. Factors influencing the effectiveness of performance measurement systems. International Journal of Operations \& Production Management, 31(12), pp.1287-1310.

Veysel, A., Topal, Y. \& Kaya, H., 2012. Linking intrapreneurship activities to multidimensional firm performance in Turkish manufacturing firms : an empirical study. International Entrepreneurship and Management Journal, 8(1), pp.15-33.

Vimal, K.E.K. \& Vinodh, S., 2013. Development of checklist for evaluating sustainability characteristics of manufacturing processes. International Journal of Process Management and Benchmarking, 3(2), pp.213-232.

Weerasinghe, R., Jayawardane, A. \& Ramlogan, R., 2014. Power of being small and entrepreneurial and essentiality of innovation for excellence in performance and global competitiveness: a case of SMEs in a developing country context. International Journal Process Management and Benchmarking, 4(3), pp.262 276.

Weible, R., 2009. Are universities reaping the available benefits internship programs offer? Journal of Education for Business, 85(2), pp.59-63.

Wickramasinghe, V. \& Perera, L., 2010. Graduates', university lecturers' and employers' perceptions towards employability skills. Education + Training, 52(3), pp.226-244.

Wilton, N., 2008. Business graduates and management jobs: an employability match made in heaven? Journal of Education and Work, 21(2), pp.143-158.

Winkel, O., 2010. Higher education reform in Germany: How the aims of the Bologna process can be simultaneously supported and missed. International Journal of Educational Management, 24(4), pp.303-313.

Wong, M. \& Cheung, R., 2014. Service improvement in Hong Kong retail banking through satisfied and committed employees. International Journal of Process Management and Benchmarking, 4(1), pp.3-21.

Yasin, M.M., Small, M., et al., 2011. An examination of the implementation and effectiveness of processes improvement initiatives in manufacturing operational systems. International Journal of Business Systems Research, 5(3), pp.344-361. 
Yasin, M.M., Bayes, P.E. \& Czuchry, A.J., 2005. The Changing Role of Accounting in Supporting the Quality and Customer Goals of Organizations: An Open System Perspective. International Journal of Management, , 22(3), pp.323-332.

Yasin, M.M., Correia, E. \& Lisboa, J. V., 2004. The profitability of customer-targeted quality improvement efforts: An empirical examination. TQM Magazine, 16(1), pp.45-49.

Yasin, M.M., Gomes, C.F. \& Miller, P.E., 2011. Competitive Strategic Grouping for Hospitals: Operational and strategic perspectives on the effective implementation of quality improvement initiatives. TQM Journal, 23(2), pp.301-312.

Yorke, M. \& Knight, P., 2007. Evidence-informed pedagogy and the enhancement of student employability. Teaching in Higher Education, 12(2), pp.157-170.

Yu, T.-Y. \& Huang, P.-T., 2014. Border innovation management, improved passenger services and satisfaction acceptance. International Journal of Process Management and Benchmarking, 4(1), pp.89-108. 
Table 1 - Profile of the most important skills impacting student internship performance

\begin{tabular}{|c|c|c|c|c|c|}
\hline Country & Institution & $\begin{array}{c}\text { Sample } \\
\text { size }\end{array}$ & Skills & Mean* & $\begin{array}{l}\text { Standard } \\
\text { deviation }\end{array}$ \\
\hline USA & East Tennessee State University & 152 & $\begin{array}{l}\text { - Relations with others } \\
\text { - Dependability } \\
\text { - Initiative } \\
\text { - Ability to learn }\end{array}$ & $\begin{array}{l}4.74 \\
4.69 \\
4.67 \\
4.63\end{array}$ & $\begin{array}{l}0.483 \\
0.489 \\
0.580 \\
0.557\end{array}$ \\
\hline Portugal & University of Coimbra & 145 & $\begin{array}{l}\text { - Collegiality } \\
\text { - Obedience } \\
\text { - Positive influence } \\
\text { - Adaptability to organizational culture }\end{array}$ & $\begin{array}{l}4.48 \\
4.33 \\
4.23 \\
4.20\end{array}$ & $\begin{array}{l}0.698 \\
0.708 \\
0.752 \\
0.847\end{array}$ \\
\hline
\end{tabular}

Notes * Scale 1 to 5 
Figure 1 - A win-win joint venture between business organizations and business education

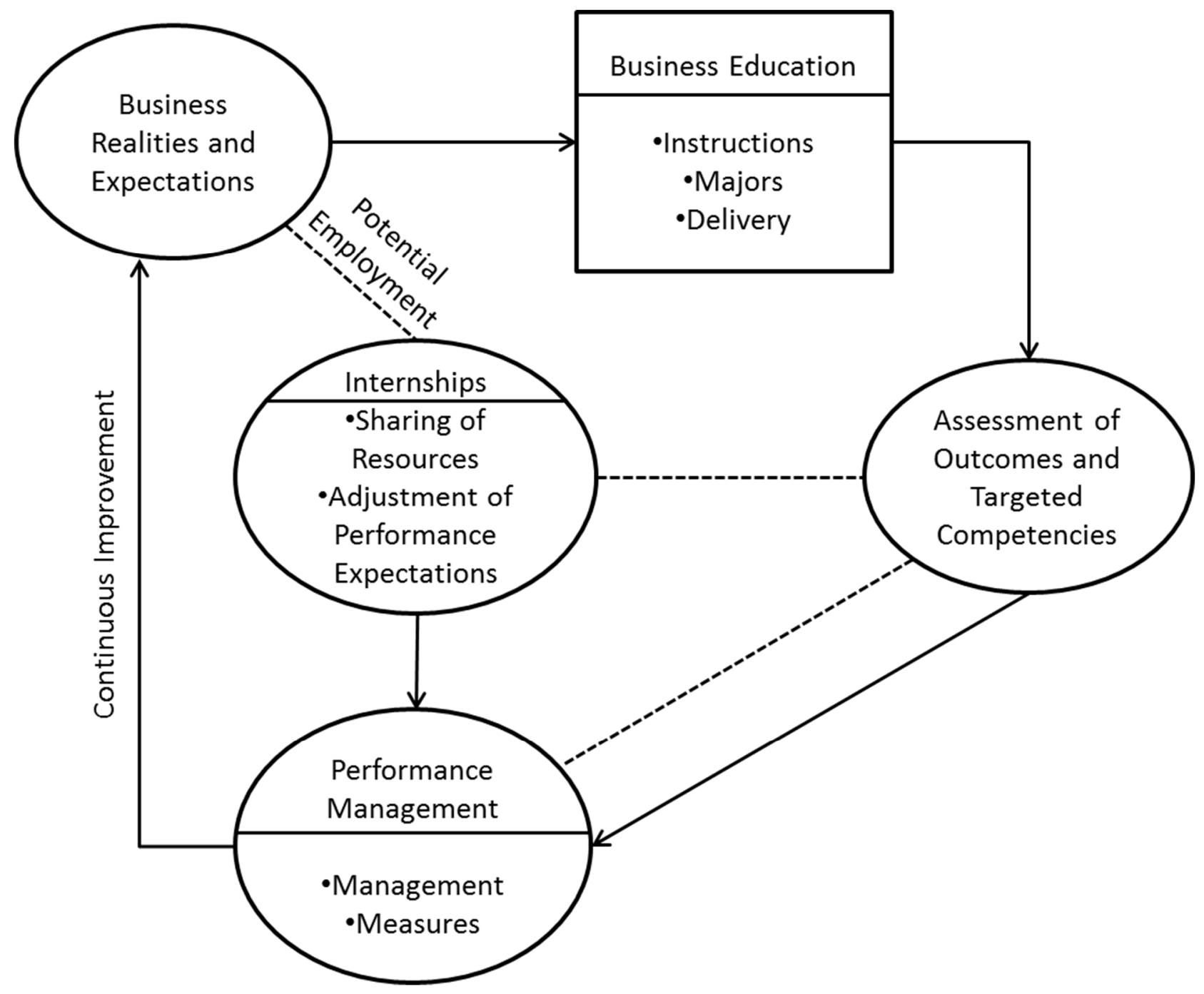


Figure 2 - A staircase approach to a win-win joint venture between business organizations and business education

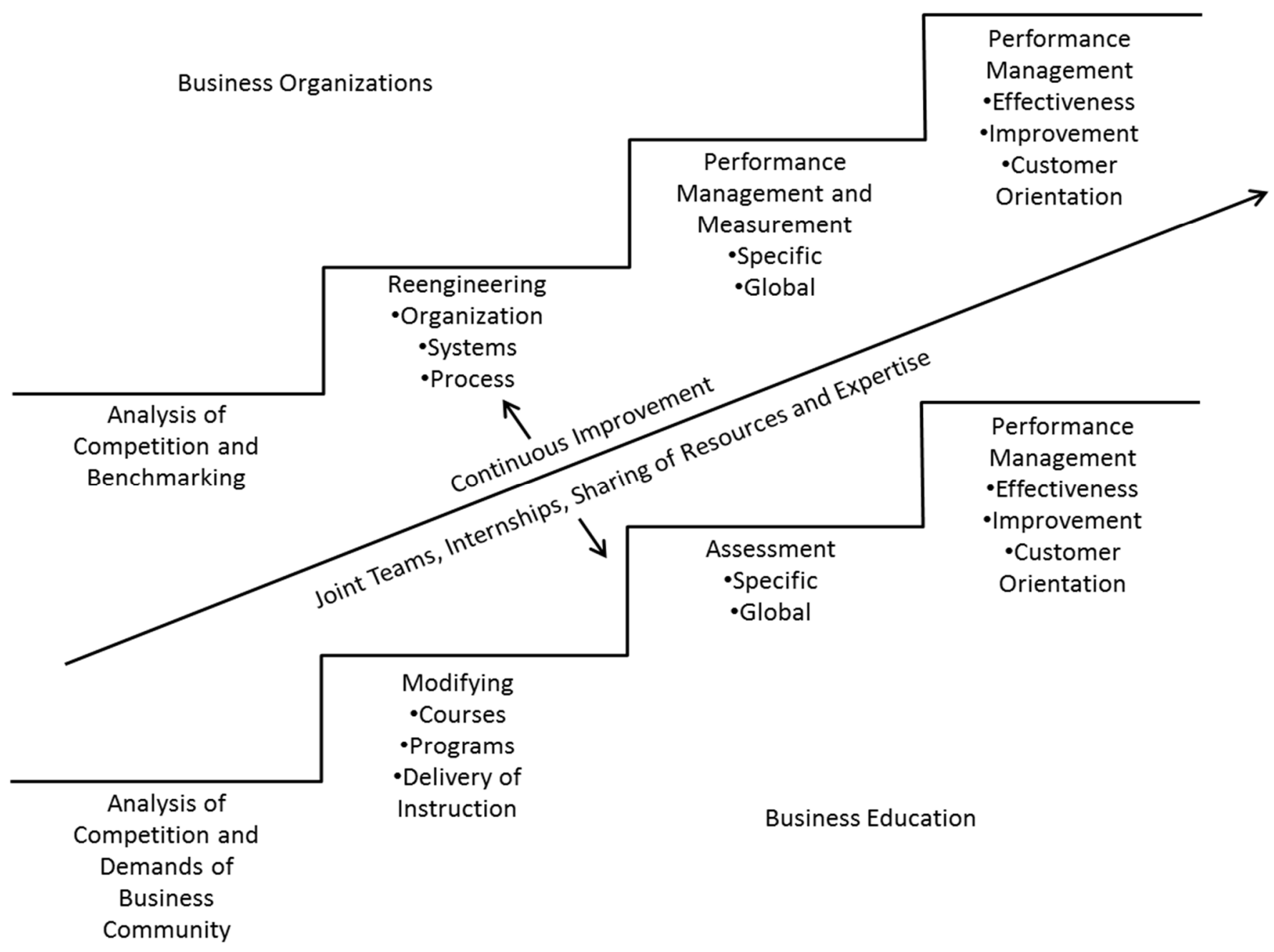

